\title{
Література:
}

1. Пожарська А.-О. Ю. Річкові острови у географічних дослідженнях. Екологічні науки. 2020. № 4(31). С. 61-65. https://doi.org/10.32846/2306-9716/2020.eco.4-31.9

2. Рулев А. С., Шинкаренко С. С., Кошелева О. Ю. Оценка влияния гидрологического режима Волги на динамику затопления острова Сарпинский. Ученые записки Казанского университета. Серия Естественные науки. 2017. № 159(1). С. 139-151.

3. Томченко О., Мазуркевич Л., Малець О. Дослідження динаміки змін берегової лінії островів Дніпра в межах Києва (на прикладі острова Великий Північний). Вісник Київського національного університету імені Тараса Шевченка. 2017. №1(66)/2(67). С. 84-88. http://doi.org/10.17721/1728-2721.2017.66.12

4. Ding D., Jiang Y., Wu Y., Shi T. Landscape Character Assessment of Water-land Ecotone in an Island Area for Landscape Environment Promotion. Journal of Cleaner Production, 2020, 259, 120934. https://doi.org/10.1016/j.jclepro.2020.120934

DOI https://doi.org/10.30525/978-9934-26-006-3-37

\section{ЗАХОДИ ПОКРАЩЕННЯ ГЕОЕКОЛОГІЧНОГО СТАНУ БАСЕЙНУ РІЧКИ ТУРІЯ}

\author{
Полянський С. В. \\ кандидат географічних наук, \\ дочент кафедри фізичної географії \\ Волинський національний університет імені Лесі Украӥнки \\ Полянська Т. О. \\ асистент кафедри міжнародних економічних відносин \\ Луиьький національний технічний університет \\ Свередюк Н. В. \\ магістрантка кафедри фізичної географії \\ Волинський національний університет імені Лесі Украӥнки \\ м. Луцьк, Україна
}

\footnotetext{
Актуальним питанням водного господарства України $\epsilon$ раціональне використання водних ресурсів малих річок. Наше сьогодення характеризується зростаючим безповоротним вилученням стоку річок, 146
} 
виконанням різних господарських робіт у межах водозборів що негативно відображається на водності, процесах самочищення і руслоформування річок, чистоті водотоків. Унаслідок зменшення стоку річкового басейну, зміни руслових процесів та забруднення вод малі річки міліють, змінюється їхня структура, а деколи вони взагалі втрачають своє господарське, екологічне й рекреаційне значення. Таким чином збільшується негативний вплив на стан басейну річки, i на стан життєдіяльності людей, які проживають в межах басейну $[1 ; 5 ; 6]$.

Оскільки процеси руслоформування залежать від умов та чинників, що діють у межах водозбору, то для оптимізації перебігу ерозійноакумулятивних процесів у руслі слід впроваджувати заходи щодо оптимізації геоекологічного стану всього водозбору.

Беручи до уваги отримані результати досліджень, положення «Водного кодексу України», Закону України «Про охорону навколишнього природного середовища», Закону України № 2988-III В «Про загальнодержавну програму розвитку водного господарства України», пропонуємо такий ряд заходів, спрямованих на оптимізацію геоекологічної стану в басейні Турії [1]:

1. 3 метою зменшення інтенсивності розвитку ерозійних процесів необхідно запровадити комплекс гідротехнічних заходів. Важливу роль у цьому комплексі відіграють штучні водоймища-регулятори (ставки). Затримуючи і регулюючи стік талих і дощових вод, вони запобігають зростанню ярів, значно знижують потрапляння часток еродованого грунту і поглинутих ними добрив та пестицидів у водні об'єкти. Водоскидні споруди, до яких належать швидкотоки, підпірні стінки, перепади i водопади $\epsilon$ найпростішими для використання 3 метою закріпленим дна ярів. ІІобудувати комплекс таких споруд необхідно у верхніх частинах меліоративних систем та у верхів’ї Турії.

2. Серед агротехнічних заходів у басейні Турії доцільним буде проведення протиерозійних способів обробітку грунту, смугове розміщення культур, створення буферних смуг. Вирішення цих завдань має стосуватися усіх сільськогосподарських підприємств, які займаються землеробством в межах територій прилеглих до водотоків досліджуваної території річкової системи [3; 4].

3. 3 метою зниження небезпеки розвитку ерозійних процесів на водозборі, які сприяють деградацію малої річки, необхідно оптимізувати співвідношення природних i перетворених господарською діяльністю територій на водозборі, особливо на ділянках у верхів’і річки (Затурці - Холопичі), на вододілі р. Серебряниця і Воронка, у верхів`і приток Воронка, Рудка, при цьому 
лісистість басейну має бути не менше 30 \%. Необхідно відмінити оранку в межах заплав. Заплави є джерелом твердого стоку: порівняно невелика відстань транспортування твердих частинок сприяе їхньому надходженю у водотік без суттєвих втрат на акумуляцію в межах заплави. В басейні річки Турія - це характерно між населеними пунктами (селами) Затурці - Холопичі, Гайки - Туричани, смт. Турійськ - Задиби, Качин - Датинь.

4. Безумовно дотримуватися положень «Водного кодексу України» стосовно цих територій - тобто повсюдно відновлювати водоохоронні зони і берегозахисні смуги.

5. У верхів'ях річок, у водоохоронних зонах та на еродованих ділянках берегів і долин необхідно збільшити площі фітонасаджень. Там, де відбулися значні вирубки лісів, розораність заплав, зумовлені інтенсивною меліорацією, природний рослинний покрив необхідно відновлювати шляхом насадження невеликих лісових масивів поблизу водотоків річок і водозахисних смуг вздовж водотоків. Для захисту корінних берегів від розмиву, а також очищення поверхневого стоку від завислих речовин лісові смуги потрібно створювати на прибережному схилі вздовж брівки корінного берега. 3 метою запобігання ерозії грунтів і водорегулювання лісові смуги необхідно розташовувати і на орних землях: в рівнинних місцевостях це мають бути грунтово-водозахисні лісові смуги; на орних землях, розміщених на схилах понад $3^{\circ}$ - стокорегулюючі лісові смуги [3; 4].

Реалізація водоохоронних заходів повинна базуватись на врахуванні динаміки водних ресурсів, басейнового планування розміщення промислових підприємств. розвитку міст, сільськогосподарського виробництва і т. д.

3 метою оптимізадії режиму функціонування річкової мережі та регулювання розвитку небезпечних гідрогеоморфологічних процесів у руслах річок, пропонуємо такі заходи:

1) підпорядкувати єдиному методично-виробничому органу (басейновому управлінню) роботу всіх регулюючих споруд;

2) здійснити інвентаризацію відкритих гідромеліоративних каналів в межах головних осушувальних систем басейну Турії, виявити ефективність i, відповідно, доцільність їхнього використання;

3) обгрунтувати заходи 3 поліпшення чи припинення функціонування гідромеліоративних каналів;

4) здійснити облаштування джерел, що живлять річку;

5) зменшити скидання неочищених стоків у річку 3 метою покращення якості річкової води та зменшення каламутності потоків 
(особливо це стосується урбанізованих ділянок річок). Впровадження та удосконалення існуючих очисних систем $є$ необхідним на р. Турія поблизу смт Турійськ, м. Ковель, тобто в місцях зосередження найбільшої кількості (або великих за обсягами скидів) промислових, житлово-комунальних, сільськогосподарських водокористувачів;

6) для активізації природних самоочисних процесів річки, покращення якості води забезпечити відновлення природних річищ. Для цього в межах існуючих магістральних каналів підтримувати природний процес відновленя меандр шляхом насадження дерев (вербової лози, кущів калини) вздовж ділянок русел річок і каналів, на яких проявляються процеси меандрування [2];

7) провести розчистку вибіркових ділянок русел з метою боротьби 3 ï замуленням, заростанням та засміченням;

8) для посилення самоочисних процесів у річках на їхніх гирлових ділянках, а також нижче населених пунктів, що найбільше забруднюють річки, створити руслові водойми-біофільтри.

Вищенаведені заходи і рекомендації, які грунтуються на вивченні умов функціонування малих річок, вважаємо базовою основою для збереження річок досліджуваного басейну, відтворення їхнього біорізноманіття, запобігання розвитку несприятливих для життєдіяльності людини гідрогеоморфологічних процесів та забезпечення їхнього позитивною впливу на геоекологічну ситуацію прилеглих територій.

\section{Література:}

1. Екологічний паспорт Ковельського району за 2018 рік. URL: https://voladm.gov.ua/article/ekologichniy-pasport-kovelskogo-rayonu/ (дата звернення: 23.11.2020).

2. Нетробчук, І. М., Миколюк Л. М. Екологічна оцінка та динаміка змін якості води річки Турія у Волинській області [Текст] / Наукові записки СумДПУ імені А. С. Макаренка. Географічні науки: збірник наукових праць. Сумський відділ; редкол.: Б. М. Нешатаєв (гол. ред.), А. О. Корнус та ін. Суми, 2018. Вип. 9. С. 69-77.

3. Полянський С. В. Агроекологічний стан грунтового покриву еталонних осушувальних систем у басейні р. Прип'ять / Наук. запис. Тернопіл. нац. пед. ун-ту ім. Володимира Гнатюка. Серія: Географія. Тернопіль: СМП «Таір», 2015. №1. Вип. 36. С. 192-200.

4. Полянський С. В. Екологічні проблеми грунтового покриву Волині. Сучасний екологічний стан та перспективи екологічно безпечного стійкого розвитку Волинської областікол: монографія / за 
ред. В. О. Фесюка. К.: ТОВ «ПІДПРИЄМСТВО «ВІ ЕН ЕЙ», 2016. C. $166-173$.

5. Паспорт річки Турія /Акціонерне товариство інститут «Волнньводпроект». Луцьк. 1994. 200 с.

6. Постанова Кабінету Міністрів України № 391 від 30 березня 1998 року «Про затвердження Положення про державну систему моніторингу довкілля» II Офіиійний вісник Украӥни. 1998. № 13. С. 91-97.

DOI https://doi.org/10.30525/978-9934-26-006-3-38

\title{
ТЕНДЕНЦІЇ У РОЗПОВСЮДЖЕННІ ВІДКЛАДЕНЬ ОЖЕЛЕДІ НА ТЕРИТОРІЇ УКРАЇНИ У ЗИМОВІ МІСЯЦІ ПРОТЯГОМ 2011-2019 рр. ВІДНОСНО ПЕРІОДУ 1981-2010 рр.
}

\author{
Пясецька C. I. \\ кандидат географічних наук, \\ старший науковий співробітник \\ Украӥнський гідрометеорологічний інститут \\ Державної служби Украӥни з надзвичайних ситуацій \\ та Національної академії наук України \\ м. Київ, Украӥна
}

Відкладення ожеледі відносяться до несприятливих погодних явищ, які перешкоджають роботі ряду гагузей економіки, що є найбільш погодозалежними від них - енергетика транспорт, комунальне господарство. Дослідження розповсюдження таких видів відкладень на території України було започатковано О.М. Раєвським на початку 60-х років XX сторіччя та продовжено у роботах В.М. Бабіченко для періоду 80-90-х років XX та початку XXI ст. відносно відкладень ожеледі стихійного характеру (СГЯ) [1-3].

Натепер, для визначення поточних тенденцій у розповсюдженні відкладень ожеледі на території Украни на сучасному етапі зміни клімату протягом 2011-2019 pp. необхідно продовжити таке дослідження та провести порівняння середньої кількісті випадків таких відкладень за цей період відносно рекомендованого ВМО 30-и річчя протягом 1981-2010 рр. Необхідність такого порівняння визначено суттєвими змінами у сучасній кліматичній системі внаслідок 